\title{
COMPARISON OF METHANOGENESIS BETWEEN SUNFLOWER AND CORN STALKS MIXED WITH PIG MANURE AT DIFFERENT TEMPERATURES
}

\author{
FENG, L. ${ }^{1}-$ YU, Q. ${ }^{1}-$ ZHEN, X. F. $.^{2 *}-$ DONG, H. Y. ${ }^{2}-$ ZHENG, J. ${ }^{3}-$ WANG, Y. ${ }^{3}$ \\ ${ }^{1}$ Liaoning Province Clean Energy Key Laboratory, Shenyang Aerospace University \\ Shenyang Daoyi Street 37, Shenyang 110136, China \\ (phone: +86-1804-0038-889) \\ ${ }^{2}$ School of New Energy and Power Engineering, Lanzhou Jiaotong University \\ No. 88, Anning West Road, Anning District, Lanzhou 730070, China \\ (phone: +86-1391-9302-012) \\ ${ }^{3}$ School of Energy and Power Engineering, Lanzhou University of Technology \\ No. 287, Langongping Road, Qilihe District, Lanzhou 730050, China \\ (phone: +86-1391-9257-393) \\ *Corresponding author \\ e-mail: farming478@outlook.com; phone: +86-1391-9302-012
}

(Received $21^{\text {st }}$ Jun 2019; accepted $16^{\text {th }}$ Oct 2019)

\begin{abstract}
The gas production effect of two kinds of straws mixed with pig manure via anaerobic fermentation under two sets of temperatures $32^{\circ} \mathrm{C}$ and $52^{\circ} \mathrm{C}$ has been studied in this experiment. In the process, sunflower and corn straw were used as raw materials with activated sludge as inoculum in a batch anaerobic fermentation reactor. The results showed that the average methane content of sunflower straw reached $62.55 \%$ at $37^{\circ} \mathrm{C}$, which was $20.41 \%$ higher than that of sunflower straw at $52^{\circ} \mathrm{C}$. The cumulative methanogenic yield of corn stalks was higher than that of sunflower stalks at different temperatures. The cumulative methane production of corn stalks was the highest at $52^{\circ} \mathrm{C}$, and $67.99 \mathrm{~L}$ of methane was produced in 54 days. The cumulative methane production of sunflower stalks was the lowest at $52^{\circ} \mathrm{C}$, and the methane production was $34.09 \mathrm{~L}$ in 53 days. The results showed that corn stalks produce more methane than sunflower stalks and are more suitable for high temperature anaerobic fermentation. On the other hand, sunflower stalks were found suitable for medium temperature fermentation.
\end{abstract}

Keywords: anaerobic fermentation, biomass, resource utilization, livestock manure, biogas

\section{Introduction}

The People's Republic of China as a large agricultural country has abundant straw resources. In 2017, the country's collectible straw production from the main crops reached 900 million tons (Liu et al., 2018). This production included the straw from corn (Zea mays L., Fam.: Poaceae) and sunflower (Helianthes annuus L., Fam.: Asteraceae). The amount was nearly more than $1 / 3$ of the total straw production of China. In China, reasonable conversion of straw to available energy is crucial field of research (Du et al., 2015). At present, a large amount of straw in China is not being effectively utilized, resulting in wastage of resources and pollution to the environment due to indiscriminate burning (Fan et al., 2018). The anaerobic fermentation technology is an effective means to ensure the utilization of straw resources and the technology can sufficiently solve the problem of straw waste management and generate renewable energy such as methane gas to alleviate the energy shortage in China (Duan et al., 2016). The effort will promote 
the sustainable development of the society and improve the economy and ecological condition of the environment (Wan et al., 2010; Jha et al., 2011; Sun, 2016).

Studies related to the methane production by straw is affected by a number of factors. Among which temperature is an important factor affecting anaerobic fermentation (Brown et al., 2012; Huang et al., 2018). It plays an important role in microbial growth rate, enzyme activity, biochemical reaction rate, etc. Generally, the anaerobic fermentation temperature is divided into three gradients: low temperature, medium temperature and high temperature (Liu et al., 2008; Yin et al., 2014). Juan et al. (2018) found that the methane production efficiency of corn straw increased with increasing temperature. During anaerobic fermentation at high temperature like $55^{\circ} \mathrm{C}$, the total organic load (TS) was $100 \mathrm{~g} / \mathrm{L}$. The yield of TS in the corn straw unit was $44.68 \%$ higher than that under the anaerobic digestion at $45^{\circ} \mathrm{C}$, which was $64.08 \%$ higher than $35^{\circ} \mathrm{C}$. Studies by Pang et al. (2018) and others showed that the cumulative methane production of anaerobic fermentation of cow manure and straw at $35^{\circ} \mathrm{C}$ was $91.84 \mathrm{~L}$, which was $20 \%$ higher than that at $25^{\circ} \mathrm{C}$ and $30^{\circ} \mathrm{C}$. Contreras et al. (2012) explored the potential for methane production in rice straw and rice at $37^{\circ} \mathrm{C}$ and $55^{\circ} \mathrm{C}$. It was found that the biogas production at high temperature was $0.43 \mathrm{~m}^{3} \cdot \mathrm{kg} / \mathrm{vs}$, which was $0.09 \mathrm{~m}^{3} \cdot \mathrm{kg} / \mathrm{vs}$ higher than that under medium temperature. It was confirmed that the high-temperature fermentation of rice straw was better.

In the present research, studies on the effects of temperature on anaerobic fermentation of different types of straw have been reported (Gu et al., 2016). Some previous studies have shown different types of gas production by using different compositions of straw. However, there exists very few studies on the effect of temperature and on the potentiality of anaerobic fermentation of sunflower straw and its anaerobicity. In order to fill up the gap between theoretical research and the application of the technology in practice, the concept of present research has been developed. In this research, using batch anaerobic fermentation reactor, the effect of gas production changes by sunflower and corn straw at $37^{\circ} \mathrm{C}$ and $52^{\circ} \mathrm{C}$ has been compared during the research, the changes of various parameters while the anaerobic fermentation of two straws were in operation have also been studied. So, the aim of the present research is to maximize the utilization of straw anaerobic fermentation, improve the resource utilization of sunflower straw and corn straw and to provide data support for straw anaerobic fermentation technology.

\section{Materials and Methods}

\section{Experiments}

The corn straw for the present study was collected from the Shenbei New District of Shenyang City, Liaoning Province, China. The whole corn was harvested and after separating the grains of the cobs, the straws were air dried and crushed. The crushed biomass of the straw was passed through a 20-mesh sieve. The source and treatment of sunflower straw were the same as those applied for the corn straw. Fresh pig manure was collected from Shenbei New District, Shenyang City, Liaoning Province. The inoculum used for the experiment was the biogas slurry collected after carrying out in vitro anaerobic fermentation. Fresh pig manure (mass ratio 1:10) was added before the experiment which was carried out at medium $\left(37^{\circ} \mathrm{C}\right)$ and high temperature $\left(52^{\circ} \mathrm{C}\right)$ for 15 
days. The characteristic parameters of the raw materials used in the anaerobic digestion processes have been presented in Table 1 .

Table 1. Presenting the characteristic parameters of anaerobic digestion feedstock

\begin{tabular}{c|c|c|c}
\hline Raw material & TS/\% Total solids & VS/\% volatile solids & C/N \\
\hline Corn straw & $89.78 \pm 0.01$ & $71.68 \pm 0.01$ & ND \\
Sunflower straw & $94.44 \pm 0.01$ & $88.64 \pm 0.01$ & ND \\
Pig manure & $29.28 \pm 0.02$ & $19.8 \pm 0.01$ & $24 \pm 0.03$ \\
Biogas slurry inoculum & $2.09 \pm 0.01$ & $0.885 \pm 0.001$ & ND \\
\hline
\end{tabular}

Data shown were the average and standard deviation based on triplicate runs; ND meant not determined

\section{Main devices}

A controllable constant temperature fermentation unit was used for carrying out the tests involved in the present investigation. The experimental protocol has been presented in Fig. 1.

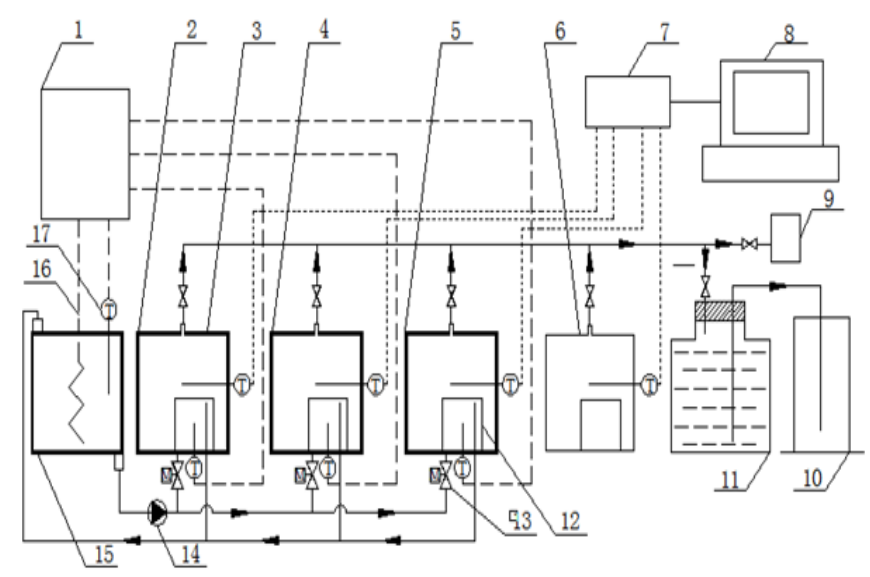

Figure 1. Schematic diagram of controllable constant-temperature fermenting equipment

1. Temperature controller 2. Insulation layer 3. Fermentation cylinder 4. Fermentation cylinder

5. Fermentation cylinder 6. Fermentation cylinder 7. Data collecting instrument 8. Computer 9.

Biogas analyzer 10. Water storage tank 11. Gas storage tank 12. Internal water tank 13.

Solenoid valve 14. Hot water pump 15. Constant temperature water tank 16. Heating wire 17.

Temperature sensor

The device is mainly composed of a heating water tank, a temperature controller, a cylindrical 304 stainless steel fermenter with an effective volume of $10 \mathrm{~L}$ (with a height to diameter ratio of 1:1) and a gas collecting device. The fermenter of the device is insulated from the environment and the temperature of the fermenter is adjusted. The flow rate of the circulating heating water tank is precisely controlled, and the temperature is measured with a Pt100 platinum resistance temperature detecting device with an accuracy of $\pm 0.1^{\circ} \mathrm{C}$.

Other instruments used for determining various other experimental parameters were: TDL-5-A centrifuge (Shanghai Anting Scientific Instrument Factory); GZX-9240MBE digital display blast drying oven (Shanghai Boxun Industrial Co., Ltd.); UV-9200 UVvisible spectrophotometer (Beijing Ruili Analytical Instruments Co., Ltd.); Biogas check 
biogas analyzer (Geotech, UK); JSM5600LV scanning electron microscope (JEOL, Japan) and D/MAX-2004 powder X-ray diffractometer (Nippon Science).

\section{Anaerobic digestion test design}

The mass ratio of corn and sunflower stalk and pig manure was 1:2 and the amount of biogas slury inoculation was $30 \%$ of the mass. The corn straw group contained: straw, pig manure, acclimated biogas slurry at the rate of $0.30 \mathrm{~kg}, 0.59 \mathrm{~kg}$ and $1.70 \mathrm{~kg}$, respectively. On the other hand, sunflower straw group contained: $0.30 \mathrm{~kg}, 0.58 \mathrm{~kg}$ and $1.69 \mathrm{~kg}$ as straw, pig manure and acclimated biogas slurry, respectively after feeding, $6.0 \mathrm{~kg}$ distilled water was added.

The fermenter has a volume of about $6 \mathrm{~L}$, and the temperature is controlled at $52 \pm 1{ }^{\circ} \mathrm{C}$ and $37 \pm 1^{\circ} \mathrm{C}$, respectively. The reaction tank is shaken 3 times per day, and the digestion process is continued until no gas is produced. The test run cycle was fixed for $54 \mathrm{~d}$. The $\mathrm{pH}$ value, gas composition and gas production of the fermentation broth were measured every 5 days, and indicators like the chemical oxygen demand (COD), volatile fatty acids (VFAs) and ammonia nitrogen $\left(\mathrm{NH}_{4}{ }^{+}-\mathrm{N}\right)$ of the fermentation broth were measured at intervals of 4 days. After the fermentation, the corn straw residue is separated, and the weight after drying was taken and recorded.

\section{Analysis methods}

The total solids (TS) and volatile solids (VS) of corn straw, sunflower straw, pig manure and biogas slurry inoculum samples were measured according to the standard methods (APHA, 1998). The biogas components were measured using a Biogas Check. The $\mathrm{pH}$ value was measured using an Oriol PHS3C portable $\mathrm{pH}$ meter. VFAs and COD determination is based on Liu et al. (2013), using spectrophotometry and potassium dichromate method respectively. While phenol sodium hypochlorite colorimetry method was used to determine $\mathrm{NH}_{4}{ }^{+}-\mathrm{N}$ concentration. The measurement of alkalinity was carried out using an acid-base indicator titration method.

Neutral detergent fiber (NDF), acid detergent fiber (ADF) and acid detergent lignin (ADL) measurements were done via Paradigm analysis. Cellulose (CL) and hemicellulose (HC) quality scores were done after ADF-ADL and NDF-ADF. The structural analysis were carried out using scanning electron microscope (SEM) as well as $\mathrm{X}$-ray diffraction (XRD).

\section{Results and Discussion}

Gas production changes of corn straw and sunflower straw under anaerobic fermentation at different temperatures

It can be seen from Figs. 2-3 that the gas production amount is significantly different depending upon the temperature and straw varieties. During the $54 \mathrm{~d}$ fermentation period, the gas yield of corn straw reached the peak at $11.72 \mathrm{~L} / \mathrm{d}$ on the $42 \mathrm{nd}$ day at $52^{\circ} \mathrm{C}$. At this temperature, the sunflower straw reached the highest daily gas production at $4.94 \mathrm{~L} / \mathrm{d}$ on the 44th day. At $37^{\circ} \mathrm{C}$, the gas yield of corn straw reached the peak at $4.83 \mathrm{~L} / \mathrm{d}$ on the $51 \mathrm{st}$ day, while the peak gas yield of sunflower straw appeared at $47 \mathrm{~d}$, which was $5.92 \mathrm{~L} / \mathrm{d}$. In contrast, the peak gas production time during high temperature fermentation at $52^{\circ} \mathrm{C}$ was earlier than that at $37^{\circ} \mathrm{C}$. In addition, the cumulative gas production of corn straw at $52^{\circ} \mathrm{C}$ was $140.31 \mathrm{~L}$ while the cumulative gas production of sunflower straw was $80.68 \mathrm{~L}$. 
On the other hand, the cumulative gas production of corn straw at $37^{\circ} \mathrm{C}$ was $92.46 \mathrm{~L}$ and the peak gas yield of sunflower straw was $67.55 \mathrm{~L}$. Cumulative total biogas production in the present investigation followed an order: $52^{\circ} \mathrm{C}$ corn straw $>37^{\circ} \mathrm{C}$ corn straw $>52^{\circ} \mathrm{C}$ sunflower straw $>37^{\circ} \mathrm{C}$ sunflower straw. The cumulative gas production of corn straw and sunflower straw at $52^{\circ} \mathrm{C}$ is higher than the cumulative gas production at $37^{\circ} \mathrm{C}$, indicating that the bioactivity of the bacteria is stronger under high temperature. During which, the decomposition efficiency of cellulose, hemicellulose and other substances is higher and the metabolic rate of microbial cells is accelerated. The anaerobic fermentation efficiency is improved. In addition, the cumulative gas production of corn straw was higher than that of sunflower straw. The daily gas production of sunflower straw during the late stage decreased to the initial stage of the reaction, indicating that the content of cellulose and other substances in sunflower straw was lower than that of corn straw. Insufficient accumulation leads to a decrease in gas production efficiency and a decrease in gas production during the later stages of methanogen production.

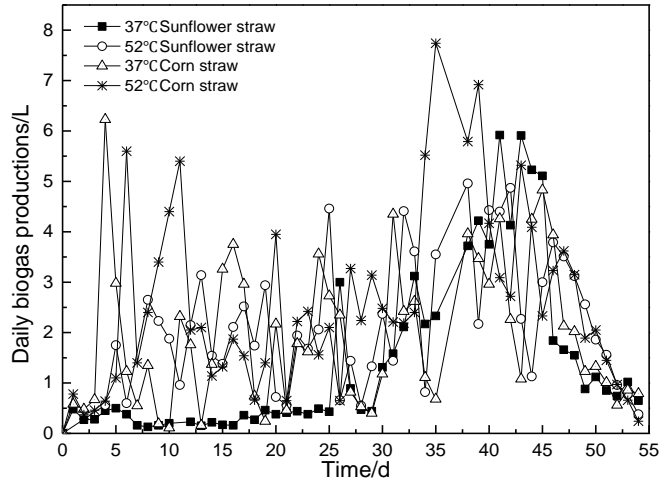

Figure 2. Daily biogas production trends of corn straw and sunflower straw at different temperatures

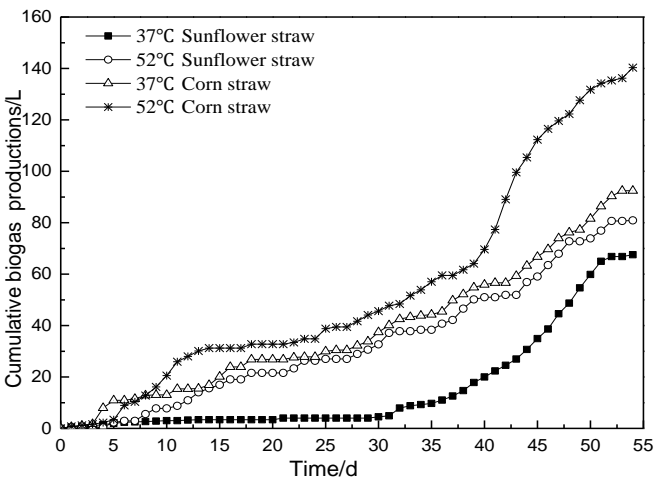

Figure 3. Cumulative biogas production trends of corn straw and sunflower straw at different temperatures

\section{Anaerobic fermentation $\mathrm{pH}$ and fatty acid changes of corn straw and sunflower straw at different temperatures}

Because, acid-producing bacteria have a wide range of $\mathrm{pH}$ adaptation and methane producing bacteria are sensitive to $\mathrm{pH}$ changes, $\mathrm{pH}$ plays a great role in the anaerobic digestion processes.

During the 54-day fermentation period, the $\mathrm{pH}$ of each group can be roughly divided into three stages: "stable-decline-fast rise". The overall $\mathrm{pH}$ of the fermentation was between 6.5 and 7.9, indicating that the self-regulating $\mathrm{pH}$ inside the fermentation can maintain a stable fluctuation range (Zhou et al., 2014). Since the added activated sludge itself is weakly alkaline, the $\mathrm{pH}$ gradually rises during the initial stage of the reaction. During the period of $18 \mathrm{~d}-30 \mathrm{~d}$, the $\mathrm{pH}$ value may decrease. It may be that the hydrolysis and acidification of the acetogenic bacteria decomposes the available materials in the straw and converts them into volatile fatty acids. At this time, the ammonia nitrogen content of the alkalinity in the fermentation system is insufficient, and the methanogens are still insufficiently adapted to the environment. A large amount of fatty acids accumulate, leading to a drop in $\mathrm{pH}$ (Fang et al., 2017). From $35 \mathrm{~d}$ to $47 \mathrm{~d}$ in the later stage of the experiment, as the reaction continued, the methanogens gradually adapted to 
the environment. As a result the activity of the strains increased and began to reproduce, consuming large amounts of fatty acids and producing ammonia nitrogen. The $\mathrm{pH}$ level rose again. As seen from figures (Fig. 4 and Fig.5) there is an opposite trend of change of $\mathrm{pH}$ and VFAs in anaerobic fermentation. During the mid-stage $\mathrm{pH}$ drop, the fatty acid concentration was at a higher value; while the $\mathrm{pH}$ value increased at the late stage of fermentation, the concentration of volatile fatty acids began to decrease rapidly.

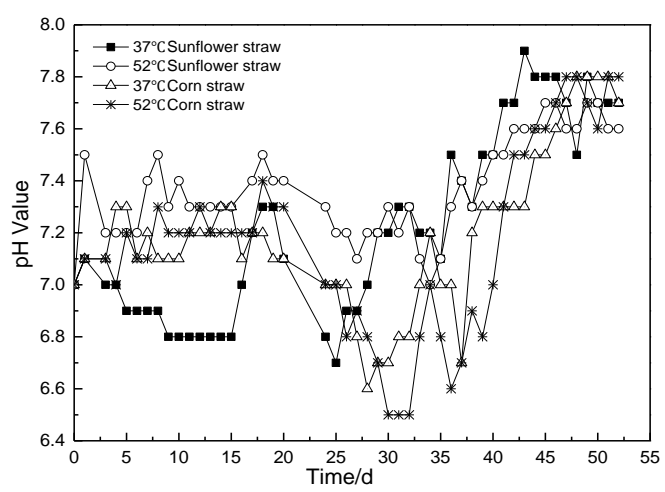

Figure 4. Change trend of $\mathrm{pH}$ value of corn straw and sunflower straw under different temperatures

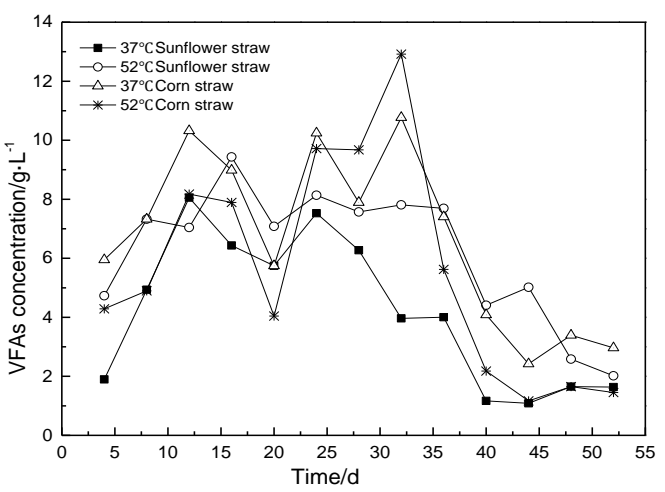

Figure 5. Change trend of volatile fatty acids concentration of corn straw and sunflower straw under different temperatures

Volatile fatty acids are important intermediary compounds for reflecting microbial metabolism during anaerobic fermentation of straw (Xu et al., 2016).

At $37^{\circ} \mathrm{C}$, sunflower straw reaches almost in the acidification and gas-free stage within 30 days before the middle temperature anaerobic digestion. However, the average concentration of VFAs was the lowest at this stage, and the theoretical inhibition intensity was the lowest, but the cumulative gas production was the lowest. The analysis showed that the sunflower stalks were under medium temperature conditions. The volatile acid produced had the highest propionic acid content, while propionic acid had the most obvious inhibitory effect on methanogens, which led to the inhibition of gas production in the first and middle stages. The average concentration of VFAs in corn straw at $37^{\circ} \mathrm{C}$ was higher than $52^{\circ} \mathrm{C}$. Although, the average content of methane in corn straw at $52^{\circ} \mathrm{C}$ and $37^{\circ} \mathrm{C}$ was not much different, only $2.8 \%$ higher, but the cumulative yield of corn straw methane at $52^{\circ} \mathrm{C}$ was much higher than that of sunflower straw. The results showed that different temperatures had different effects on the methanogenesis of sunflower straw and corn straw. At $37^{\circ} \mathrm{C}$, the methane production increased rapidly and the average methane content was the highest. The analysis showed that the methanogens used acetic acid, the acetic acid content decreased, and the acetic acid was resistant to propionic acid. Oxygen digestion has the strongest inhibitory effect. The decrease in acetic acid content leads to an increase in the degradation ability of propionic acid, and the gas production efficiency of methanogens increases. The content of VFAs decreased at the beginning of $52^{\circ} \mathrm{C}$ corn straw for 30 days. At the same time, the methane production grew rapidly and the average methane content was higher than $37^{\circ} \mathrm{C}$, indicating that corn straw was more suitable for $52^{\circ} \mathrm{C}$ high temperature anaerobic fermentation.

\section{Ammonia nitrogen concentration changes in corn straw and sunflower straw under} anaerobic fermentation at different temperatures 
The change of ammonia nitrogen concentration is an important parameter for the stability of the reaction fermentation system. It can be seen from Fig. 6 that the average ammonia nitrogen value of sunflower straw is $1.19 \mathrm{~g} / \mathrm{L}$ at $37^{\circ} \mathrm{C}$ and $1.87 \mathrm{~g} / \mathrm{L}$ at $52^{\circ} \mathrm{C}$ and the average ammonia nitrogen value of corn straw at $37^{\circ} \mathrm{C}$ is $1.85 \mathrm{~g} / \mathrm{L}$ and at $52^{\circ} \mathrm{C}$, it is 1.98. $\mathrm{g} / \mathrm{L}$. At $37^{\circ} \mathrm{C}$, the ammonia nitrogen concentration and $\mathrm{pH}$ of the sunflower straw fermentation were lower than other groups. It may be that at $37^{\circ} \mathrm{C}$ sunflower straw has higher activity of acid-producing bacteria at this stage, while the methanogen has not adapted to the environment, resulting in low ammonia nitrogen concentration. On the 40th day of fermentation, the daily methane production of sunflower straw increased significantly at $37^{\circ} \mathrm{C}$. It is known from Figure 4 that the $\mathrm{pH}$ increased rapidly. At this stage, the ammonia nitrogen concentration decreased rapidly and the volatile fatty acid reached the lowest value (Lin et al., 2011). It indicated that low concentration of ammonia nitrogen can promote the proliferation and division of methanogens and increase the yield of methane, which is consistent with the experimental study of Shun et al. (2018).

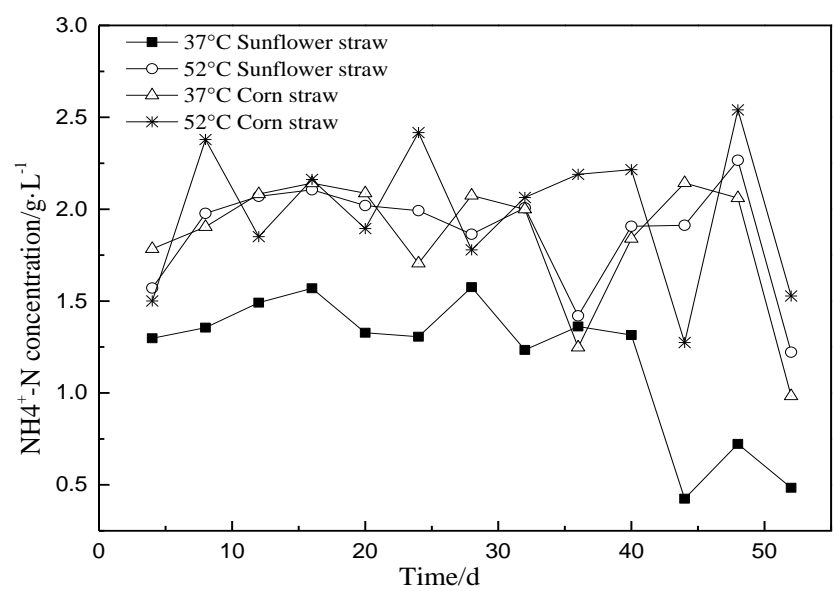

Figure 6. Change trend of ammonia nitrogen concentration of corn straw and sunflower straw under different temperatures

The average concentration of ammonia nitrogen in high temperature anaerobic fermentation of corn straw and sunflower straw was higher than that of medium temperature anaerobic fermentation. In the appropriate temperature range, as the temperature increases, the activity of the strain gradually increases resulting an increasing rate of ammonia nitrogen.

\section{Anaerobic methanogenesis of corn straw and sunflower straw at different temperatures}

It can be seen from Figs. 7-8 that the methane production in the middle and early days before the reaction is low, and in the late, rate rises rapidly, The peak value appears between $42 \mathrm{~d}$ and $51 \mathrm{~d}$, and the gas production fluctuates greatly, indicating that the experimental fermentation factors are excessive. At the temperature of $52^{\circ} \mathrm{C}$, the methanogenic rate of corn stalks increased rapidly from $40 \mathrm{~d}$ to $44 \mathrm{~d}$. It was found that a large amount of methanogenic precursors such as acetic acid, formic acid, ethanol and $\mathrm{CO}_{2}$ were formed in the middle and early stages of corn stalks at the same temperature. Methanogens can be utilized, and gas production increases, leading to peak values. The peak daily methane production of sunflower straw at $37^{\circ} \mathrm{C}$ and sunflower straw at $52^{\circ} \mathrm{C}$ 
was $47 \mathrm{~d}$ and $44 \mathrm{~d}$, respectively. The peaks of daily methane production at $37^{\circ} \mathrm{C}$ and $52^{\circ} \mathrm{C}$ of corn straw were $51 \mathrm{~d}$ and $42 \mathrm{~d}$, respectively. It can be seen that as the temperature increases, the peak value of the daily methane gas conversion is advanced. However, there is no such rule in methane production. From Table 2, the highest content of methane in corn stalks at $52^{\circ} \mathrm{C}$ is $73.7 \%$, while the highest methane content in corn stalks at $37^{\circ} \mathrm{C}$ is $70.9 \%$. However, sunflower straw and corn stalks showed an opposite trend. The maximum content of methane from sunflower straw at $37^{\circ} \mathrm{C}$ was $78.37 \%$, while the same at $52^{\circ} \mathrm{C}$ was only $58.70 \%$. It can be speculated that the cumulative methane production of corn stalks increases with increasing temperature within a certain temperature range. The accumulated methane production of sunflower straw at $37^{\circ} \mathrm{C}$ was higher than $52^{\circ} \mathrm{C}$. The result showed that $37^{\circ} \mathrm{C}$ was closer to the optimum temperature of sunflower straw anaerobic fermentation. While the activity of methanogen was inhibited at $52^{\circ} \mathrm{C}$, and the methane production decreased.

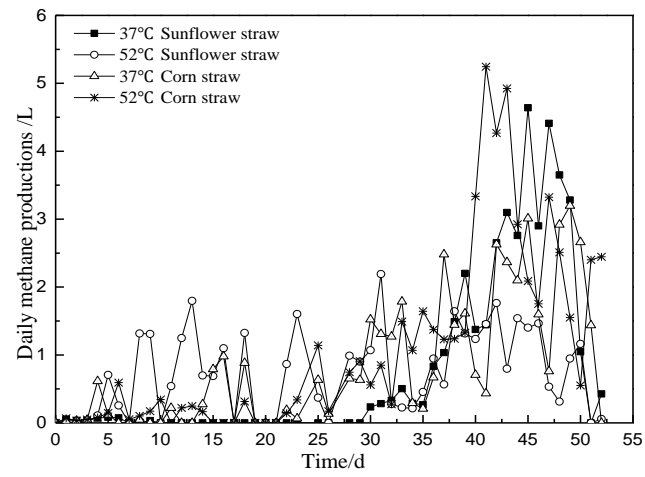

Figure 7. Daily methane production of corn straw and sunflower straw under different temperatures

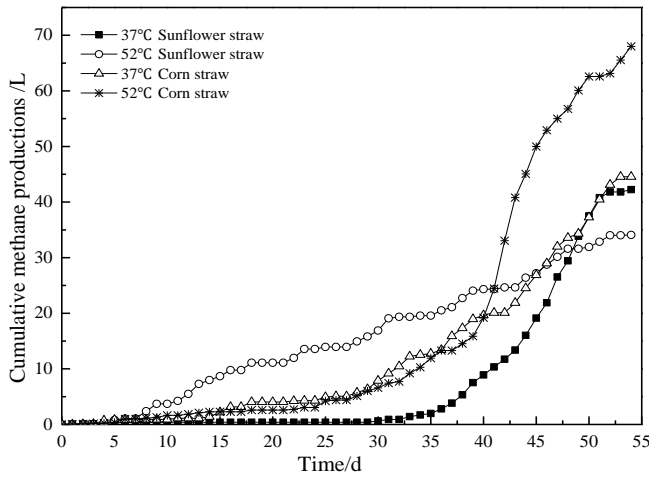

Figure 8. Cumulative methane production of corn straw and sunflower straw under different temperatures

Table 2. Biogas production and methane production changes

\begin{tabular}{c|c|c|c|c}
\hline Grouping & $\begin{array}{c}\text { Sunflower straw } \\
\text { at } \mathbf{3 7}{ }^{\circ} \mathbf{C}\end{array}$ & $\begin{array}{c}\text { Sunflower straw } \\
\mathbf{a t ~ 5 2}^{\circ} \mathbf{C}\end{array}$ & $\begin{array}{c}\text { Corn straw } \\
\mathbf{a t ~ 3 7}^{\circ} \mathbf{C}\end{array}$ & $\begin{array}{c}\text { Corn straw } \\
\mathbf{a t ~ 5 2}^{\circ} \mathbf{C}\end{array}$ \\
\hline Daily biogas productions/L & 1.25 & 1.49 & 1.71 & 2.59 \\
TS biogas productions $/ \mathrm{L} \cdot \mathrm{kg}^{-1} \mathrm{TS}$ & 141.35 & 169.27 & 193.53 & 293.69 \\
VS biogas productions $/ \mathrm{L} \cdot \mathrm{kg}^{-1} \mathrm{VS}$ & 175.06 & 209.64 & 266.59 & 404.55 \\
TS methane productions $/ \mathrm{L} \cdot \mathrm{kg}^{-1} \mathrm{TS}$ & 88.41 & 71.33 & 93.28 & 142.32 \\
VS methane productions $/ \mathrm{L} \cdot \mathrm{kg}^{-1} \mathrm{VS}$ & 109.45 & 88.34 & 128.49 & 196.05 \\
Average methane content\% & 62.55 & 42.14 & 48.20 & 48.46 \\
Maximum methane content\% & 78.37 & 58.70 & 70.90 & 73.70 \\
\hline
\end{tabular}

\section{Conclusions}

From the present investigation, experiments show that temperature has a significant effect on the gas production characteristics of combined sunflower straw and corn straw anaerobic fermentation.

In the 100-day fermentation test, the cumulative methane production of corn stalk at $52^{\circ} \mathrm{C}$ was $77.99 \mathrm{~L}$, which was $128.77 \%$ higher than that of anaerobic fermentation of sunflower straw at the same temperature. When the fermentation temperature was 
maintained at $37^{\circ} \mathrm{C}$, the cumulative production of methane from sunflower straw The lowest amount, only 34.09 L. However, the average content of methane in sunflower straw at the fermentation temperature of $37^{\circ} \mathrm{C}$ was $62.55 \%$, which was higher than the average content of corn stalks at 37 degrees Celsius and sunflower stalks at 52 degrees Celsius by $14.35 \%$ and $20.41 \%$. In general, in order to improve the methane yield of anaerobic fermentation of straw, corn straw is more suitable for anaerobic fermentation at high temperature $\left(52^{\circ} \mathrm{C}\right)$. Unlike corn straw, sunflower straw is more suitable for anaerobic fermentation at medium temperature $\left(37^{\circ} \mathrm{C}\right)$.

The methane production characteristics of straw and pig manure under medium and high temperature anaerobic fermentation conditions were studied. It was proved that corn stalk and pig manure could effectively improve the $\mathrm{C} / \mathrm{N}$ ratio of materials and improve anaerobic digestion efficiency, and synergistically in anaerobic fermentation.

There is no research on low temperature $\left(<15^{\circ} \mathrm{C}\right)$. The winter temperature in northern China is low, and the anaerobic mixing of straw and pig manure at low temperature is studied. Fermentation has high value for the utilization of biomass resources.

Acknowledgements. This work was funded by the National Natural Science Foundation project (51509122), and Gansu Provincial Higher Education Science and Technology Achievements Transformation Project (2018D-04), Gansu Natural Science Foundation (18JR3RA154), 2018 Yangling Demonstration Zone Collaborative Innovation Major Project (2018CXY-14).

\section{REFERENCES}

[1] APHA (1998): Standard Methods for the Examination of Water and Wastewater. - 18th ed., American Public Health Association, DC, US.

[2] Brown, D., Shi, J., Li, Y. (2012): Comparison of solid-state to liquid anaerobic digestion of lignocellulosic feedstocks for biogas production. - Bioresource Technology 124(11): 379-386.

[3] Chen, G., Du, J., Chang, Z., Ye, X., Xu, Y., Zhang, J. (2014): Characteristics of biogas producing by anaerobic co-digestion of agricultural straw and swine wastewater based on improved straw-bed bioreactor. - Transactions of the Chinese Society of Agricultural Engineering 30(20): 244-251.

[4] Contreras, L. M., Schelle, H., Sebrango, C. R., Pereda, I. (2012): Methane potential and biodegradability of rice straw, rice husk and rice residues from the drying process. - Water Science \& Technology, A Journal of the International Association on Water Pollution Research 65(6): 1142-9.

[5] Du, J., Chen, G.-Y., Ye, X.-M., Fu, G.-Q. (2015): Effects of contact ratio of straw and free fermentation liquid on characteristics of anaerobic fermentation. - China Environmental Science 35(03): 811-816.

[6] Duan, X., Wang, X., Xie, J., Feng, L., Yan, Y., Zhou, Q. (2016): Effect of nonylphenol on volatile fatty acids accumulation during anaerobic fermentation of waste activated sludge. - Water Research 105: 209-217.

[7] Fan, X. S., Liu, C. R., Li, Y. C. et al. (2018): Influence of $\mathrm{Fe}_{2}\left(\mathrm{SO}_{4}\right)_{3}$ on the biogas production in the anaerobic fermentation system with rice straw and pig manure. - Journal of Safety and Environment 18(03): 1159-1165.

[8] Fang, W., Ye, J., Zhang, P., Zhu, X., Zhou, S. (2017): Solid-state anaerobic fermentation of spent mushroom compost for volatile fatty acids production by $\mathrm{pH}$ regulation. International Journal of Hydrogen Energy 42(27): 18295-18300. 
[9] Fleming, R. A., Barclay, H. J., Candau, J. N. (2002): Scaling-up an autoregressive timeseries model (of spruce budworm population dynamics) changes its qualitative behaviour. - Ecological Modelling 149(1-2): 127-142.

[10] Gu, Q., Chang, S. X., Wang, Z.-P., Feng, J.-C., Chen, Q.-S., Han, X.-G. (2016): Microbial versus non-microbial methane releases from fresh soils at different temperatures. Geoderma 284: 178-184.

[11] He, S., Xian, P., Li, Z., Tan, S., Xiong, H., Deng, Q., Liu, Q., Li, T., Huang, Y. (2018): Anaerobic fermentation characteristics of sludge mixed with banana straw. - Chinese Journal of Environmental Engineering 12(9): 2658-2663.

[12] Huang, J. H., Wang, H. J., Huang, T. et al. (2018): Effects of temperature, salt content and oil content on combined anaerobic fermentation of kitchen waste and sludge. - Chemical Industry Management 483(12): 21-23.

[13] Jha, A. K., Li, J. Z., Nies, L., Zhang, L. G. (2011): Research advances in dry anaerobic digestion process of solid organic wastes. - African Journal of Biotechnology 10(65): 14242-14253.

[14] Li, J., Pang, Y. Z., Yuan, H. R. et al. (2018): Enhancing Methane Production from Corn Stalk by Mesophilic and Thermophilic Anaerobic Digestion. - China Biogas 36(01): 7680 .

[15] Lin, C., Wang, Y., Hou, J., Hou, Y. (2011): Effects of bacterial protein and urea addition on straw anaerobic fermentation. - Transactions of the Chinese Society of Agricultural Engineering 27(1): 74-78.

[16] Liu, C. F., Yuan, X. Z., Zeng, G. M., Li, W. W., Li, J. (2008): Prediction of methane yield at optimum $\mathrm{pH}$ for anaerobic digestion of organic fraction of municipal solid waste. Bioresource Technology 99(4): 882-888.

[17] Liu, S. Q., Zhang, W. D., Yin, F. (2013): Biogas fermentation experiment tutorial. Chemical Industry Press.

[18] Liu, Y., Zhao, L. X., Shen, Y. J. et al. (2018): Carbon and Nitrogen Changes in the Whole Process of Agricultural Waste Anaerobic Fermentation and Its residue Utilization as Fertilizer. - China Biogas 36(01): 65-70.

[19] Pang, Z. P., Li, Y. P., Zhu, J. N., et al. (2018): Effects of Different Temperatures on Biogas Production from Anaerobic Fermentation of Cow Manure and Tomato Straw. - Journal of Shan xi Agricultural Sciences 46(08): 1338-1343.

[20] Sun, Z., Zhang, J., Liu, Y., Wu, Y., Liu, D., Ma, W. (2016): Biochemical methane potential and kinetics of anaerobic digestion of cattle manure campared with corn straw. - Chinese Journal of Environmental Engineering 10(03): 1468-1474.

[21] Wan, C. Y., Huang, F. F., Liu, R., Li, W., Deng, Q. (2010): Effect on increasing biogas production using rape straw by microbiological pretreatment. - Transactions of the CSAE 26(6): 267-271.

[22] Xu, X. J. (2018): Analysis of Silage Technology of Corn Straw Feed. - Chinese Journal of Animal Husbandry and Veterinary Medicine 5: 232-232.

[23] Zhou, Q., Liu, Y., Zou, D., Zhu, B., Yuan, H., Li, X. (2014): Methane Production Performance of Anaerobic Co-digestion of Food Waste and Corn Stalk. - China Biogas 32(01): 27-31, 48 . 